\title{
The exchange of self-incriminating information of athletes between sports organisations and law enforcement
}

\author{
Björn Hessert ${ }^{1,2}$ (D) \\ Accepted: 7 July 2021 / Published online: 20 July 2021 \\ (c) The Author(s) 2021
}

\begin{abstract}
Sports organisations generally have the burden of proving sports rule violations of sportspersons subject to their rules and regulations. Sports rule violations can generally be proven by any reliable means. A common approach taken by sports organisations in this respect is the implementation of so-called cooperation and reporting obligations embedded in their regulations. On this basis, athletes can be obliged to provide all kind of documentary evidence related or unrelated to the matter under investigation. This may cause problems to the privilege against self-incrimination of athletes. In addition, obtaining self-incriminating information in internal sports investigations carried out by private sports organisations can have legal and personal consequences that go well beyond the professional life of athletes. The integrity of sport has been characterised as a public interest due to the social impact of amateur and professional sports in most societies. As a consequence, negative sports-related conduct, such as doping or the manipulation of sports competitions, has been criminalised in various national laws to protect sporting values and preserve the role model function of athletes for young members of our society. This development has led to cooperation between sports organisations and law enforcement agencies, such as prosecutors and the police. Specifically, both collaborate in order to assist the other party's investigations of sports rule violations and criminal offences, respectively. However, the exchange of intelligence between sports organisations and law enforcement may cause some legal tension. If the same misconduct of athletes leads to both internal sports investigations and criminal proceedings, athletes could be forced to provide self-incriminating information in internal sports organisations, which could then be subsequently transmitted to law enforcement. This system of intelligence gathering raises serious concerns regarding the procedural fairness thereof, keeping in mind the detrimental effects for sportspersons under investigations. A closer look is thus necessary to the legitimacy of the exchange of intelligence. Therefore, the aim of this article is to shed some light on this issue and clarify if and under what conditions internally obtained evidence can be passed on to law enforcement agencies.
\end{abstract}

Keywords Sports investigations $\cdot$ Exchange of information $\cdot$ Privilege against self-incrimination $\cdot$ Doping $\cdot$ The manipulation of sports competitions $\cdot$ Rights of athletes

\section{Introduction}

Sports investigations are of increasing importance for national and international sports organisations. Cases become more complex and complicated due to the use of evasive means by perpetrators. To cope with these new challenges in sport, sports organisations and national governments have established (independent) integrity units. For

\footnotetext{
Björn Hessert

bjoern.hessert@rwi.uzh.ch; hessert.sportslaw@gmail.com

Melbourne, Australia

2 University of Zurich, Zurich, Switzerland
}

example, the sports governing bodies for the sport of athletics and tennis have set up the Athletics Integrity Unit and the International Tennis Integrity Agency, respectively. Another example in international sports is the Biathlon Integrity Unit. In addition, the Australian government has recently established an integrity body called "Sport Integrity Australia". Sports Integrity Units, regardless whether established by sports organisations or national governments, are generally tasked with investigating and prosecuting alleged sports rule violations for the purpose of protecting the integrity of sport. To this end, sports integrity units are vested with investigatory powers to gather cogent evidence to meet the burden of proof, which generally rests on the investigating sports 
organisation. ${ }^{1}$ The investigatory measures are embedded in the rules and regulations of sports associations. Due to the monopolistic nature of national and international sports federations, athletes ${ }^{2}$, in principal, have no choice whether or not they want to accept the investigatory measures contained in the rules and regulations of their respective sports organisation if they wish to participate in organised sport. In other words, athletes are generally forced to accept preventive and repressive investigatory measures to pursue their professional career in sport. ${ }^{3}$ For example, athletes must generally accept cooperation and reporting obligations by signing an athlete's agreement, licence agreement, or other entry forms with reference to the respective rules and regulations. ${ }^{4}$ Additionally, sportspersons may face long-term ineligibility sanctions as a consequence of their failure to report or cooperate. ${ }^{5}$ This is evidenced, for example, by the recently imposed sanctions by the Athletics Integrity Unit on former officials of Russian Athletics Federation ("RusAF"), who were-inter alia - charged for their failure to cooperate under Article 5.10.3 of the then applicable IAAF AntiDoping Rules during the investigations conducted against them. ${ }^{6}$ Accordingly, this generally accepted practice among international sports organisations is a double-edge sword. It has proven to be an effective and efficient measure to gather compelling evidence to combat all threats to the integrity of sport. The use of coercive measures during internal sports investigations can also have deterrent effects on athletes. However, at the same time, it reinforces the (inner) constraints of investigated athletes and raises questions in relation to the athletes' privilege against self-incrimination in sports investigations. ${ }^{7}$

\footnotetext{
1 See, e.g. Rigozzi and Quinn (2014) 1, 30; Hessert (2020a), 145, 146; McLean (2020) 37, 38 et seq. with further information on the coercive powers of the National Sports Tribunal.

${ }^{2}$ Unless otherwise stated, the term "athlete" also refers to other persons subject to the rules and regulations of sports associations, e.g. athlete support personnel or executives.

${ }^{3}$ Mutatis mutandis Mutu and Pechstein v. Switzerland, ECtHR, Application No. 40575/10 \& 67474/10, 2 October 2018, para. 113; contra CAS 2017/A/5003, Jérôme Valcke v. FIFA, Award of 27 July 2018, paras 265, 266.

${ }^{4}$ Hessert (2020a), 145, 146 et seq.

5 See, e.g. CAS 2019/A/6459, Juan Carlos Saez v. Professional Tennis Integrity Officers (PTIOs) \& ATP Tour Inc. (ATP) \& Grand Slam Board (GSB) \& International tennis Federation (ITF) \& WTA Tour Inc. (WTA), Award of 25 March 2021.

${ }^{6}$ World Athletics v. Artur Karamyan \& Dmitry Shlyakhtin, SR/352/2019, decision of 8 February 2021; see further the decisions taken against Alexander Parkin, Elena Orlova and Elena Ikonnikova available at <https://www.athleticsintegrity.org/disciplinary-process/ first-instance-decisions $>$ accessed 25 March 2021.

${ }^{7}$ Hessert (2020a), 145-156.
}

The array of coercive measures is supposedly very limited. ${ }^{8}$ However, a closer look reveals that sports organisations can resort to important tools to investigate asserted rule violations of their direct and indirect members. This may include the submission to urine and blood sample collection, strip-searching ${ }^{9}$, search of property ${ }^{10}$, the provision of personal devices for forensic examination or the obligation to provide answers during sports interrogations. The threshold for sports organisations to resort to investigatory powers is fairly low. In repressive sports investigation proceedings, most sports regulations refer to a threshold of "believe" or "reasonably believe" ${ }^{11}$ One example of cooperation obligations can be found in Article 14.2 of the Badminton World Federation ("BWF") Judicial Procedures ("BWF JP") which provides that "Covered Persons shall cooperate with any investigation and disciplinary process carried out under these Procedures, including, without limitation, by providing accurately, completely and without undue delay any information and/or record and/or documentation and/or access or assistance requested as part of such investigation or disciplinary process". This example shows that the obligations imposed on the investigated athlete can be stringent and may appear disproportionate in relation to their fundamental procedural and privacy rights (personality rights), including personal data.

Such regulations are particularly concerning if one keeps in mind that athletes can be subject to both sports disciplinary procedures and criminal proceedings for the same act. The parallelism of these proceedings is due to the fact that sports-related conduct has been criminalised in various national criminal laws. This is particularly the case for doping and the manipulation of sports competitions but may also be true for unethical behaviour and corruption in sport. The cooperation between sports organisations and law enforcement may be necessary for various reasons. First, the investigatory power of sports organisations is limited to their direct and indirect members. Second, law enforcement agencies may be able to resort to a broader set of coercive measures under the national criminal procedure code. Third, in some

\footnotetext{
${ }^{8}$ See, e.g. CAS 2017/A/5003, Jérôme Valcke v. FIFA, Award of 27 July 2018, para 265.

9 See, e.g. WADA's International Standard for Testing and Investigations, art C.4.8.

${ }^{10}$ Press Release, "UCI update on testing for technological fraud during the 2018 Tour de France" (UCI, 30 July $2018<$ https://www.uci. org/inside-uci/press-releases/uci-update-on-testing-for-technologi cal-fraud-during-the-2018-tour-de-france> accessed 24 March 2021; ICC's Minimum Standards for Players' and Match Officials Areas at International Matches ("ICC PMOA"), art 6.1.7.

11 See, e.g. BWF JP, art 12.1 ("believe"); Tennis Anti-Corruption Program (2021 edition) s F.2.d ("believe"); World Athletics AntiDoping Rules (2020 edition) art 5.10.4 ("reasonably believe").
} 
instances, police and prosecutors might become aware of criminal conduct only after they have been informed by sports organisations.

In situations in which athletes are compelled to provide self-incriminating information during sports interrogations, the question occurs whether or not such information can be legally transmitted from sports organisations to law enforcement. In this discussion, it must also be considered that the stakeholders involved in the information sharing process may circumvent the system and act arbitrarily. For example, sports organisations could serve a notice of charge upon an (innocent) athlete in order to carry out investigations on behalf of law enforcement authorities, using coercive measures that would not be applicable under national criminal procedure law. ${ }^{12}$ If one accepts that sports organisations are legally entitled to compel athletes to disclose-inter aliaself-incriminating information for internal investigatory and adjudicatory purposes (quod non), it must be ensured that (i) information is transmitted fairly and (ii) without the miscarriage of justice.

Against this background, this article focuses on the procedural legitimacy of the exchange of information between sports organisations and law enforcement authorities. In particular, the article offers different approaches to find thorough solutions to the legal tensions associated with the transmission of self-incriminating information to public authorities. In this regard, it also considers the position held by the Swiss Federal Tribunal ("SFT") in the Valcke ${ }^{13}$ case in which the Court held that

'il est vrai que le grief du recourant soulève des questions particulièrement intéressantes ayant trait à l'application et à la portée du principe nemo tenetur se ipsum accusare dans une procédure disciplinaire au sein d'une association de droit privé alors qu'une procédure pénale portant sur les mêmes faits est pendante ou envisagée.' (emphasis added)

[free translation: it is true that Appellant's grievance raises particularly questions relating to the application and scope of the principle nemo tenetur se ipsum accusare in a disciplinary procedure within a private law association while criminal proceedings relating to the same facts are pending or contemplated.]

Part II of this article provides a brief overview of sports regulations and mandatory statutory provisions on the exchange of information between sports entities and public authorities. Part III considers possible solutions, taking into

\footnotetext{
12 CAS 2017/A/5003, Jérôme Valcke v. FIFA, Award of 27 July 2018, para 266.

13 SFT 4A_540/2018, decision of 7 May 2019, para. 3.2 (emphasis added).
}

account the interests of all athletes, sports associations, and law enforcement. Part IV finally concludes that athletes may invoke their privilege against self-incrimination in internal sports investigations if this information can be used as evidence in criminal proceedings related to the same sportsrelated conduct. The analysis will generally be based on Swiss law, given its importance in organised sport as the seat of many international sports federations and the Court of Arbitration for Sport (CAS). ${ }^{14}$

\section{Sports regulations and legislative provisions on the exchange of information}

It is commonly accepted that efforts of both sports organisations and state actors are needed to combat threats to the integrity of sport. In their endeavour to fight doping in sport, private international sports organisations have become signatories to the WADA Code by signing a declaration of acceptance. ${ }^{15}$ These Signatories have-inter alia - the obligation to implement the provisions listed in Article 23.2.2 of the WADA Code "without substantive changes". This provision fosters the harmonisation of the national and international fight against doping. Signatories must also implement WADA's International Standards. Both, the WADA Code and the International Standards contain pertinent provisions in relation to the exchange of information gathered in any part of doping control. ${ }^{16}$ Article 22.5 of the WADA Code calls on national governments - that have ratified the UNESCO International Convention against Doping in Sport ${ }^{17}$ to take legislative actions to enable the smooth exchange of information between stakeholders. In addition, Article 8.3 of the International Standard for the Protection of Privacy and Personal Information ("ISPPPI") provides-in its pertinent parts-that

'Anti-Doping Organizations may disclose Personal Information to Third Parties where such disclosures:

\footnotetext{
${ }^{14}$ Cf. Code of Sports-related Arbitration (CAS Code; 2021 edition) arts R45 and R58.

${ }^{15}$ See World Anti-Doping Code (2021 edition; "WADA Code") art 23.1.2.

16 The WADA Code defines the term "Doping Control" as "[a]ll steps and processes from test distribution planning through to ultimate disposition of any appeal and the enforcement of Consequences, including all steps and processes in between, including but not limited to, Testing, investigations, whereabouts, TUEs, Sample collection and handling, laboratory analysis, Results management and investigations or proceedings relating to violations of Article 10.14 (Statuts During Ineligibility and Provisional Suspension".

${ }^{17}$ International Convention against Doping in Sport, open for signature 19 October 2005, 2419 UNTS 201 (entered into force 1 February 2007).
} 
$[\ldots]$

c) Are necessary to assist law enforcement or governmental or other authorities in the detection, investigation or prosecution of a criminal offence, breach of professional conduct rules, or breach of the Code; provided that the Personal Information is reasonably relevant to the offence or breach in question and cannot otherwise reasonably be obtained by the relevant authorities.'

This provision explicitly refers to the purpose of the exchange of intelligence with law enforcement authorities. In this case, the information leaves the inner sports circle, more specifically the sports investigation and prosecution stage. Accordingly, the sole purpose of the act of passing information to police or prosecutors is, thus, the assistance of criminal investigations conducted by law enforcement. In other words, it no longer has any connection to its initial purpose, i.e. the investigation and prosecution of antidoping rule violations. This finding is not only important for the justification under data protection law, which will not be discussed in this article, but also for procedural aspects in the light of the principle of proportionality. Therefore, the interest of sports organisations to support investigation proceedings of third parties, i.e. public authorities, must be considered when balancing the interests of both sports organisations and investigated athletes.

The exchange of information between private sports organisations and law enforcement is also addressed in provisions aiming at combatting sports competition manipulation. This fight is differently structured than the fight for doping-free sport as an equivalent document to the WADA Code is not in place. However, a similar cooperation can be explored when looking at the respective sports regulations on match manipulation or the Council of Europe Convention on the Manipulation of Sports Competition ${ }^{18}$ ("Macolin Convention"). For example, when obtaining the International Tennis Federation International Tennis Player Identification Number ("IPIN"), professional tennis players agree to comply with the Tennis Anti-Corruption Program ("TACP"). With regard to the assistance of criminal investigations, Section F.2.d of the TACP provides-inter alia-that "any information furnished to the [International Tennis Integrity Agency] (i) kept confidential except when it becomes necessary to disclose such information in furtherance of the prosecution of a Corruption Offence, or when such information is reported to [...] judicial authorities pursuant to an investigation or prosecution of non-sporting laws or regulations [...]". Similar regulations are contained

\footnotetext{
18 Convention on the Manipulation of Sports Competition, opened for signature 18 September 2014, CETS No 215 (entered into force 1 September 2019).
}

in, e.g. Article 13.1.3 of the BWF JP or Article 4.4.4 of the ICC Anti-Corruption Code for Participants ("ICC ACC"). ${ }^{19}$ Such sports regulations are in line with provisions contained in the Macolin Convention, which is the first international convention for the purpose of harmonising and coordinating the fight against all forms of sports competition manipulation. ${ }^{20}$ Article 12 of the Convention emphasise the importance of the exchange of information in the fight against the manipulation of sports competitions. Additionally, Article 13 of the Convention refers to so-called "national platforms". National platforms are information hubs to collect information provided by, among others, sports organisations, law enforcement agencies, and sports betting operators at a national level. ${ }^{21}$ Therefore, all information gathered during sports investigations and criminal investigations, regardless whether the information is of a self-incriminating nature or not, shall be submitted to the national platform and then disseminated with other stakeholders in support of their own investigations.

In all the above-mentioned scenarios, where information is transmitted from sports organisations to public authorities, the question arises whether self-incriminating information obtained in internal sports investigation proceedings may be legally transmitted directly to public authorities or national platforms. The answer to this question is the subject of the following section.

\section{Legal solutions to the exchange of self-incriminating information of athletes}

A legal tension generally arises when information that was obtained on compelled basis is passed on to law enforcement. Forced provision of information is generally given where athletes may only choose between disclosing selfincriminating information in compliance of their reporting and cooperation obligations or refusing to comply with an information request and being potentially sanctioned for the failure to report or cooperate. Consequently, the exchange

\footnotetext{
${ }^{19}$ ICC Anti-Corruption Code for Participants, art 4.4.4 reads as follows: "Any information furnished to the ACU General Manager (whether pursuant to a specific Demand or otherwise as part of an investigation) will not be used for any purpose other than in accordance with the Anti-Corruption Code and will be kept strictly confidential except when it becomes necessary(because the information gathered may also amount to or evidence infringements of other applicable laws or regulations) to disclose such information to other competent authorities (including any applicable police, taxation, fraud, criminal intelligence or other authorities), whether pursuant to formal information-sharing agreements or otherwise".

${ }^{20}$ Hessert (2020b) 133, 140; Diaconu et al. (2021) para 2.

21 See, e.g. Trunz (2016) p. 323; Divitcos (2020) 1, 16.
} 
of self-incriminating information is of less concern if the athlete provides such information voluntarily or sua sponte. This may be the case if athletes provide their mobile phone for forensic examination during sports interrogations before a notice of disclosure has been served upon them. In this case, the privilege against self-incrimination is not applicable and the athlete's invocation thereof is generally doomed to fail.

Accordingly, the solutions to the problem of intelligence sharing between sports organisations and law enforcement authorities generally relate to situations where athletes are compelled to provide incriminating information. In this regard, it must also be emphasised that the legitimacy to pass on incriminating information to law enforcement cannot be based on the argument that athletes waive their fundamental procedural rights for the purpose of sports investigation proceedings, as for example provided in Section F.2.e of the TACP or Article 4.5 of the ICC ACC. However, this abrogation of the prohibition of self-incrimination emanating from the rules and regulations of sports governing bodies, in principle, also has a coercive character and thus cannot be considered valid. ${ }^{22}$

\subsection{Pending or contemplated criminal proceedings}

The starting point for the discussion on the legitimacy of the exchange of information between sports organisations and law enforcement is the Valcke decision of the SFT. In this context, it should be recalled that the SFT expressed concerns about the dilemma of sportspersons under investigation and explained that they may invoke the privilege against self-incrimination in internal sports investigation proceedings where criminal proceedings regarding the same matter are already pending or contemplated. ${ }^{23}$ The consequences of the view taken by the SFT are threefold. First, sports organisations may not use self-incriminating information for internal disciplinary proceedings if the investigated athlete relies upon the principle of nemo tenetur se ipsum accusare, while criminal proceedings are at least contemplated. Second, if such intelligence cannot be gathered by sports organisations, it must-argumentum a fortiori-also not be passed on to law enforcement in support of their criminal proceedings. Otherwise, the protection of the athletes' fundamental procedural rights in internal sports investigations would have no external effect. Third, sportspersons cannot refer to the privilege against self-incrimination in internal sports organisations if the information obtained only leads to the initiation of criminal proceedings.

\footnotetext{
${ }^{22}$ Mutatis mutandis SFT 4P.172/2006, decision of 22 March 2007, para 4.4.2.
}

23 SFT 4A_540/2018, decision of 7 May 2019, para 3.2.
However, from a legal standpoint, it appears to be questionable whether or not the criterion of "pending or contemplated criminal proceedings" is a suitable factor to determine the invocation of the privilege against self-incrimination in sports disciplinary proceedings that also have consequences for the transmission of information to law enforcement. This criterion may be ambiguous and can therefore lead to arbitrary results to the detriment of the investigated of the athlete concerned. This potential risk associated with the criterion of pending and contemplated criminal proceedings can be demonstrated through the following example:

Player A has been alleged of match manipulation by deliberately losing game 2 of the second set. This kind of conduct constitutes a violation of the disciplinary code of the respective sport that expressly provides that "spot fixing", i.e. influencing any aspect of a match, is prohibited. The sports governing body serves a notice of charge upon the athlete in which she is also demanded to attend a hearing with the responsible hearing officer. At the same time, the prosecutor commences criminal investigations against the athlete based on the same facts of the case due to the criminalisation of spot fixing under the applicable national criminal code. However, neither the athlete nor the investigating sports governing body has been informed about the initiation of criminal proceedings.

In the light of the Valcke decision of the SFT, player A would have the right to invoke her privilege against selfincrimination while being interviewed by the hearing officer on behalf of the investigating sports association. The obvious problem with the criterion of "pending or contemplated" is that it is an objective element to determine the relevant material time without the parties concerned having subjectively knowledge of the internal investigation proceedings of third parties, i.e. the investigations conducted by law enforcement. This risk is generally present, taking into account that criminal proceedings could - theoretically — be initiated anywhere in the world as a result of the international dimension of match manipulation. Accordingly, athletes may still be compelled to provide incriminating information during sports interrogations without respecting the legitimate ground of defence being observed when sharing such information with law enforcement. In protection of the athlete, the prohibition of self-incrimination could be retroactively re-established for the purpose of internal sports investigations, meaning that the information may not be admissible as evidence in sports disciplinary proceedings. However, this may not prevent incriminating information from being shared with law enforcement. For example, sports organisations may transmit incriminating information to law enforcement before it becomes aware that criminal proceedings were already pending or, at least, contemplated. In this case, the incriminating 
intelligence - at the time of the conducted sports investigations-may have already been obtained illegally. The use of illegally obtained evidence does not automatically lead to it being inadmissible in criminal proceedings, but that is rather subject to a balancing process between the interest of finding the truth and the procedural rights of the person concerned. ${ }^{24}$ Therefore, illegally obtained evidence will only be excluded if it amounts to a violation of the procedural Swiss public policy under Article 190 para 2 lit e) of the Swiss Federal Act on Private International Law ("PILA"). ${ }^{25}$ In this case, the actual prohibition against self-incrimination to be granted during disciplinary proceedings may thus be ineffective in parallel criminal proceedings conducted against athletes.

Furthermore, there is an inherent risk of miscarriage of justice. This is because sports organisations and law enforcement agencies could undermine the criterion of pending or contemplated by delaying the criminal proceedings until the internal sports investigation proceedings have been completed. In other words, both investigating authorities would have it in their own hands whether or not athletes can invoke the nemo tenetur principle in disciplinary proceedings. In the author's view, no further explanation is needed to describe this potential risk as seriously concerning. In this regard, it cannot be concurred with the view taken by the CAS in the Valcke case where the Panel limited the applicability of the prohibition against self-incrimination in sports investigation proceedings to already pending criminal proceedings: ${ }^{26}$

'[T]he danger that the result of such cooperation in fact-finding may at a later point trigger a criminal proceedings is - per se - not a valid justification to invoke the privilege of self-incrimination.'

This statement of the CAS Panel in Valcke is not entirely wrong. However, it lacks the required distinction between the different purposes of the investigation. In this regard, it is required to take the specific circumstances of each individual case into consideration. In repressive sports investigations, meaning that the investigated sportsperson is already alleged of a specific sports rule violation, the risk of the prescribed arbitrary application of mandatory cooperation obligations is present. In this situation, the alleged offence has also already taken place and the investigated sportsperson may therefore be the subject of parallel investigations conducted by sports organisations and law enforcement. Therefore, athletes must

\footnotetext{
${ }^{24}$ SFT 4A_448/2013, decision of 27 March 2014, para 3.2.2.

25 For general information on the ground of the violation of Swiss public policy see Beloff et al. (2021) paras D2.191 et seq.

${ }^{26}$ CAS 2017/A/5003, Jérôme Valcke v. FIFA, Award of 27 July 2018, para 266.
}

be protected from any miscarriage of justice in repressive sports investigations.

The legal situation is, however, different in preventive sports investigation proceedings. For example, sample collection proceedings to prevent doping in sport or the search of property (e.g. bags) to combat match manipulation in sport serve the overarching purpose of combating all forms of manipulation in sports effectively and efficiently. Preventive sports investigations shall generally have a deterrent effect on athletes not to engage in any form of misconduct. The detection of those athletes who cheat is an important side effect of this overall fight against doping, sports competition manipulation, and other forms of unethical behaviour. Therefore, the privilege against self-incrimination can generally not be invoked as this would cause the ineffectiveness of the entire system to combat all forms of manipulation in sport at national and international level. Accordingly, an athlete may, for example, not refuse to provide urine or blood samples on the grounds of the nemo tenetur principle. ${ }^{27}$ Otherwise, the efficiency of preventive investigative measures would be on the line and would ultimately have adverse effects on the fairness of sports competitions.

In the light of the above, the state of criminal proceedings cannot constitute the decisive line to determine between the invocation and abrogation of the privilege against selfincrimination in situations where athletes are potentially criminally investigated on the same facts of the case. It is therefore rather required to look at the purpose of the investigation. The CAS also expressed this in the above-mentioned decision when the Panel stated as follows: ${ }^{28}$

'[A] fatal blow would be stricken to the fight against doping if an athlete asked to undergo a surprise doping control were able to invoke the privilege against self-incrimination to avoid delivering a urine or blood sample, simply because in the country where the sample is collected there is an ongoing or expected criminal investigation on doping which could implicate that athlete [...].'

In summary, the criterion of pending and contemplated criminal proceedings - suggested by the SFT — appears to be arbitrary. It is deemed to create legal uncertainty and miscarriages of justice to the detriment of athletes under sports and criminal investigations. By corollary, the state of criminal proceedings cannot be the decisive factor to determine whether self-incriminating information may be legally gathered and - ultimately - transmitted from sports organisations to law enforcement agencies. Therefore, alternative

\footnotetext{
27 Contra Orth (2021) p. 311.

28 CAS 2017/A/5003, Jérôme Valcke v. FIFA, Award of 27 July 2018, para 266.
} 
legal solutions in respect of both the interest of finding the truth and guaranteeing fundamental procedural rights need to be taken into consideration.

\subsection{Exclusion of internally gathered intelligence}

The prevention of the miscarriage of justice at the investigation stage is not a concern unique to sports investigations. In other areas of law, it is usually regulated by national legislation that persons under investigations must mandatorily provide all kind of information, including incriminating documentary evidence. However, in comparison to the approach taken by the CAS and recommended by the SFT in Valcke, national legislation clearly distinguishes between internal and external investigation proceedings in protection of the defence rights of the investigated sportsperson in criminal proceedings. Such a legislative approach can be explored, for example, in s 97(1) of the German Insolvency Code ("GIC"). In German insolvency proceedings, debtors are generally obliged to divulge all information, regardless of its incriminating nature, to the insolvency administrator or insolvency court (among others). At the same time, the GIC explicitly provides that this information may only be used for internal purposes and that it cannot be used against the debtor in criminal proceedings. In this regard, s 97(1) of the GIC provides as follows:

'Der Schuldner ist verpflichtet, dem Insolvenzgericht, dem Insolvenzverwalter, dem Gläubigerausschuß und auf Anordnung des Gerichts der Gläubigerversammlung über alle das Verfahren betreffenden Verhältnisse Auskunft zu geben. Er hat auch Tatsachen zu offenbaren, die geeignet sind, eine Verfolgung wegen einer Straftat oder einer Ordnungswidrigkeit herbeizuführen. Jedoch darf eine Auskunft, die der Schuldner gemäß seiner Verpflichtung nach Satz 1 erteilt, in einem Strafverfahren oder in einem Verfahren nach dem Gesetz über Ordnungswidrigkeiten gegen den Schuldner oder einen in $\S 52$ Abs. 1 der Strafprozeßordnung bezeichneten Angehörigen des Schuldners nur mit Zustimmung des Schuldners verwendet werden'.

[free translation: The debtor shall disclose any circumstances relating to the insolvency proceedings to the insolvency court, the insolvency administrator, the creditors' committee and, if so ordered by the insolvency court, to the creditors' assembly. He shall also disclose any facts able to bring about criminal prosecution for commission of a criminal or administrative offence. However, any fact disclosed by the debtor under his obligation in accordance with the first sentence may not be used against the debtor without his consent in trial or proceedings under the Administra- tive Offences Act (Gesetz über Ordnungswidrigkeiten) brought against the debtor or a relation mentioned at section 52 subsection (1) of the Code of Criminal Procedure.]

Accordingly, the German legislator recognises the risk that the debtor may be forced to provide incriminating information in their insolvency proceedings while criminal proceedings could already be initiated or are contemplated in parallel. The third sentence of s 97(1) of the GIC must therefore be construed to mean that incriminating evidence is barred, independent from the status of criminal proceedings. In other words, the purpose of the last sentence of s 97(1) of the GIC is to ensure that the privilege against self-incrimination is not indirectly circumvented during insolvency proceedings for the sake of criminal prosecution. In turn, the debtor is not allowed to invoke the principle nemo tenetur se ipsum accusare in internal insolvency proceedings. ${ }^{29}$

The mandatory provision of documentary evidence for exclusive internal use can also be discovered in parallel administrative and criminal proceedings under Swiss law. For example, Article 29 of the Federal Act on the Swiss Financial Market Supervisory Authority ("FINMASA") provides that supervised persons have the obligation to disclose all requested information (para. 1) and report all incidents of substantial importance (para. 2) to the Financial Market Supervisory Authority ("FINMA"). The FINMA may even impose sanctions of up to 100,000 Swiss Francs for the failure to cooperate in administrative proceedings pursuant to Article 48 of the FINMASA. Interestingly, in contrast to the "Valke approach", the majority of legal literature and the Swiss government seem to prefer a similar approach with regard to the (in)admissibility of incriminating evidence as provided under s 97(1) of the GIC mentioned above. ${ }^{30}$ Accordingly, the person under investigation is, in principle, obliged to provide all information in the course of administrative proceedings. ${ }^{31}$ However, information of an incriminating nature may then not be used as evidence in criminal proceedings. ${ }^{32}$ Similar approaches are also applied in tax and insolvency proceedings under Swiss law. ${ }^{33}$

These situations are not fundamentally different for athletes in sports investigation proceedings. Regulations of international sports federations expressly stipulate that

\footnotetext{
${ }^{29}$ Lüke (2017) s 97, para 5.

30 Geth (2014) 105, 119; Macula (2016) 30, $41 \mathrm{ff}$; contra Truffer (2019) art 29, para 22 who argues in favour of invoking the prohibition of self-incrimination in FINMA administrative proceedings.

31 See SFT 142 IV 207, decision of 30 May 2016, para. 8.3.2 in which the Court distinguishes between administrative obligation and criminal coercion; see also Boss (2020) 7, 12.

32 Geth (2014) 105, 119.

33 Macula (2016) 30, 41; Truffer (2019) art 29, para 21.
} 
information can generally be shared with law enforcement agencies for the assistance of criminal investigations. However, the situation of athletes is comparable to debtors under s 97(1) of the GIC or supervised persons under Article 29 of the FINMASA. Sportspersons generally do not have a genuine choice whether to disclose or withhold information, as they face severe repercussions either in the form of sporting sanctions or in the (indirect) incrimination in criminal proceedings. Because of the similarities in sports investigations and insolvency and administrative proceedings described, one possible solution to deal with the dilemma of athletes could be the limitation of evidential admissibility to internal sporting purposes. In addition, if information collected in public administrative proceedings cannot be used in criminal proceedings, incriminating information obtained in private (sports) investigation proceedings may-argumentum a fortiori-be disregarded in criminal proceedings.

If one follows this line of argument, sports organisations would be permitted to resort to the investigatory measure of cooperation obligations by serving a notice of disclosure upon the investigated athlete. To fulfil their cooperation obligations, athletes would still be forced to disclose all requested information, including self-incriminating information, for example, contained in their emails or on their social media accounts, mobile phones or other electronic devices. In this case, the interest of sports organisations in investigating asserted sports rule violations, on the one hand, and the protection of fundamental procedural rights of athletes in external criminal proceedings, on the other hand, would be respected. Such an approach would also address the need to treat all athletes equally in sports investigations, while national criminal procedure laws may vary considerably. Consequently, sports organisations would be prohibited from sharing incriminating information obtained in the course of internal sports investigation proceedings, regardless of the status of criminal prosecution, unless this information was provided on voluntary basis or the athlete gives consent to its admissibility in criminal proceedings.

\subsection{Duty of loyalty as direct and indirect members of sports organisations}

Sports organisations are generally founded under private association or company law. This private legal personality must also be considered in the discussion about the invocation of the privilege against self-incrimination in internal sports investigations. Under Swiss law, this principle may only be invoked in investigations conducted by public authorities. ${ }^{34}$ Due to the private nature of sports

\footnotetext{
34 SFT 131 IV 36, decision of 22 December 2004, para E.3.3.1; see also Swiss Criminal Procedure Code, art 113(1): “...in particular, the accused is entitled to refuse to make a statement or to cooperate in the criminal proceedings...".
}

investigation proceedings, sportspersons may not be entitled to invoke their privilege against self-incrimination while being investigated for violations of sports rules.

Private internal investigations are not alien to Swiss law and other legal systems. Under Swiss employment law, for example, it is generally accepted that employees have a fiduciary duty towards their employers to provide all information, including incriminating evidence, during internal investigations. ${ }^{35}$ This obligation is attributed to Article $321 \mathrm{a}(1)$ of the Swiss Code of Obligations ("CO"). ${ }^{36}$ However, in a recent decision, the SFT has raised concerns about the scope of the employee's obligation. ${ }^{37}$ In particular, the Court affirmed that certain defence rights must also be guaranteed when serious allegations against the employee are investigated. In this case, an employee must at least be informed about the alleged misconduct and the right to counsel prior to the interrogation. ${ }^{38}$ The Court, however, did not comment on the invocation of the prohibition of self-incrimination, which is probably due to the specific circumstances of the case. However, as a general principle, it appears that the question of whether or not a particular defence right is afforded to employees under investigation is subject to a balancing process. This balancing process must generally consider the employees' duty of loyalty under Article 321a(1) of the $\mathrm{CO}$ and the employers' duty of care towards their employees under Article 328 of the CO. ${ }^{39}$ The same balancing process must apply to the question of whether the privilege against self-incrimination can be invoked in internal investigations carried out by the employer. In the affirmative, it seems consistent that information obtained in violation of the nemo tenetur principle should then be inadmissible as evidence in criminal proceedings brought against the employee on the same facts. ${ }^{40}$

The legal obligation of sportspersons to cooperate with their respective sports organisation in sports investigation proceedings does not derive from Swiss association law. Cooperation obligations that are not at least incorporated into the statutes of an association cannot be considered as loyalty duties of members vis-à-vis their sports organisations. ${ }^{41}$ Whether indirect members would be bound by such explicit obligations contained in association statutes can be

\footnotetext{
35 See, e.g. Graf (2016) 39, 40; Boss (2020) 7, 13; Higher Court (Obergericht) Zurich, decision of 8 February 2017, UE160149, para 7.3.

${ }^{36} \mathrm{CO}$, art $321 \mathrm{a}(1)$ reads as follows: "The employee must carry out the work assigned to him with due care and loyally safeguard the employer's legitimate interest".

37 SFT 4A_694/2015, para. 2.4 .

38 Ibid.

39 Rudolph (2018) 385, 389.

${ }^{40}$ Graf (2016) 39, 43; Rudolph (2018) 385, 393.

${ }^{41}$ Riemer (1990) art 70, papa 193.
} 
left open, because a duty to cooperate, which is similar to the employees' duty to cooperate under Article 321a(1) of the OR, generally arises out of sports rules and regulations on the basis of a contractual relationship between sports organisations and athletes. Sports organisations conduct private internal investigations in which sportspersons are compelled to disclose all information, including information of an incriminating nature, upon request. If the aforementioned principles of Swiss employment law are applied to sports investigation proceedings, the result is different from the findings examined in relation to administrative proceedings. Accordingly, sportspersons could invoke their privilege against self-incrimination in internal sports investigations and thereby withhold information that could possibly incriminate them in criminal proceedings. Furthermore, any information obtained in violation of this fundamental procedural principle would then be inadmissible in criminal proceedings.

This solution is obviously detrimental to the main purpose of internal sports investigations, i.e. the detection and prosecution of sports rule violations. Athletes could rely on the nemo tenetur principle without opportunities for review by the investigating sports organisation. In order to ensure procedural fairness in consideration of the interests of all parties involved, athletes could have the obligation to provide all requested information upon request for verification purposes. This procedure would then be similar to discovery proceedings well known in US procedure law. ${ }^{42}$ The athlete would then have to raise the issue of incrimination when providing information to sports organisations. In addition, the investigated athlete would have to specify what particular document and information raises concerns about their privilege against self-incrimination. This way, sportspersons would also fulfil their cooperation obligations and would not fear a sanction for non-compliance thereof. In order to counterbalance the adverse effects associated with the disclosure of information, the sports organisation —or ideally an operationally and institutionally independent integrity body - would then have to examine whether the athlete's invocation of the prohibition of incrimination is based on substantiated grounds. This review would also have to consider the probative value for potential criminal proceedings against the athlete, which makes this task extremely difficult. In the affirmative, the sports organisation is prevented from using this information as evidence against the investigated

\footnotetext{
${ }^{42}$ However, privileged information (e.g. protected under the Fifth Amendment) may be withhold, for example, in United States Federal Courts based on Rule 26(b)(1) of the Federal Rules of Civil Procedure: "Unless otherwise limited by court order, the scope of discovery is as follows: Parties may obtain discovery regarding any nonprivileged matter that is relevant to any party's claim or defense and proportional to the needs of the case...".
}

athlete and needs to delete such information. However, if the information is not of an incriminating nature, sports organisations can rely on this information in their sports proceedings and are ultimately not prevented from sharing this information with law enforcement.

\subsection{Probative value and exclusion of evidence}

Further considerations to balance the procedural rights of investigated athletes, on the one hand, and the finding of the truth of sports organisations and law enforcement agencies, on the other, could refer to measures undertaken by the SFT in criminal matters. In this regard, two different approaches can be explored: (i) the general exclusion of self-incriminating evidence obtained in internal investigations ${ }^{43}$ and (ii) the examination of the probative value by the competent criminal court ${ }^{44}$. The latter is of particular interest to the present discussion in the light of a recent decision of the SFT, in which the Court emphasised that the admissibility of evidence may be determined upon the probative value for criminal proceedings. ${ }^{45}$ However, the SFT further found that admissibility must be decided in due considerations of the coercive nature and the prohibition of self-incrimination. ${ }^{46}$ In other words, the question of admissibility of incriminating evidence in criminal proceedings is subject to a balancing process that takes into account the probative value for criminal proceedings and the fundamental procedural rights of the accused person according to the circumstances of the individual case. If one follows this view, sports organisations would be entitled to transmit all evidence and information obtained in internal sports investigation proceedings to law enforcement authorities. It would ultimately be up to the discretion of the individual judge to decide whether or not incriminating evidence obtained by coercion is admissible as evidence against athletes in criminal proceedings.

\subsection{Miranda rights}

The admissibility of incriminating evidence could also be made conditional on compliance with (modified) Miranda rights, meaning that athletes under investigation must be properly informed during their sports investigations/interrogations about the possible use of self-incriminating information in criminal proceedings ${ }^{47}$ In turn, evidence obtained

\footnotetext{
${ }^{43}$ SFT SK.2010.7, 16 June 2010, para. 3.1.

44 SFT 6B_48/2020 and 6B_49/2020, decision of 26 May 2020, para. 5.3;

45 SFT 6B_48/2020 and 6B_49/2020, decision of 26 May 2020, para. 5.3 .

46 Ibid; Boss (2020) 7, 17.

47 Orth (2021) p. 314.
} 
without a Miranda warning in internal sports proceedings may then be excluded from criminal proceeding as evidence against athletes. ${ }^{48}$ According to this view, athletes nevertheless cannot invoke the nemo tenetur principle in sports investigation proceedings. ${ }^{49}$ This Miranda rights solution is, however, not very convincing and must therefore be dismissed from the outset for the following reasons: athletes are compelled to provide information and documentary evidence during sports investigation proceedings. The Miranda rights solution appears to be oxymoronic because the sports investigator would first inform the athlete that all information could be used against her or him in criminal proceedings while the athlete would then be forced to disclose all information on the basis of the sports regulations in avoidance of sporting sanctions. In this case, the evidence obtained would — based on the Miranda rights solution-be admissible as evidence in criminal proceedings. Therefore, the Miranda rights solution increases the dilemma of athletes and would thus legitimise the use of self-incriminating evidence forcibly obtained in criminal proceedings to the detriment of athletes' fundamental procedural rights. It also seems to be questionable whether the investigating sports association has to inform athletes about the possible use of evidence in criminal proceedings if the applicable sports regulations provide for this. Athletes have consented to such rules and regulations and should therefore be generally aware of their contents. The mere provision of Miranda warnings in sports investigation proceedings is not practice-oriented, particularly in repressive sports proceedings, and therefore cannot be considered a meaningful approach to solving the problem of collecting and exchanging self-incriminating evidence in parallel sports and criminal proceedings.

\section{In the sporting interest}

The collaboration between sports organisations and law enforcement agencies poses a risk to the fundamental procedural rights of athletes under investigation. The legal tension arising from the interest of sports organisations, on the one hand, and the defence rights of athletes in sports and criminal proceedings, on the other, need to be solved in consideration of the purpose of sports investigation proceedings. The sole purpose for sports organisations to conduct internal investigations is to detect and prosecute sports rule violations. The assistance of criminal investigations is only a side effect of the criminalisation of sports-related conduct in recent years. In the interest of sport, it appears to be legitimate that athletes need to support internal investigations of

\footnotetext{
48 Ibid.

49 Ibid.
}

sports organisations in protection of the integrity of sport. Sportspersons have an obligation to abide by the rules and regulations of their respective sports federation. It therefore deems to be appropriate to find the truth about sports rules violations internally in a fair and reasonable manner. In consideration of the interests at stake, it seems legitimate to compel athletes to provide information for the benefit of protecting the integrity of sport and maintaining a level playing field. The situation of athletes is therefore comparable with the dilemma faced by debtors, employees or companies described above.

However, the forced nature of the disclosure of all kind of information, including self-incriminating information, plays a significant role in answering the question whether the exchange of information between sports organisations and law enforcement agencies is compatible with the defence rights of athletes in criminal proceedings. In this regard, the words of the SFT in the Valcke decision must be remembered where the Court stated that "Appellant's grievance raises particularly questions relating to the application and scope of the principle nemo tenetur se ipsum accusare in a disciplinary procedure within a private law association while criminal proceedings relating to the same facts are pending or contemplated". However, the concerns raised by the SFT are also present in cases where criminal proceedings are not yet pending or contemplated. Therefore, the criterion pointed out in the Valcke decision cannot be considered as the right approach.

The athlete's privilege against self-incrimination cannot depend on the state of criminal proceedings, as this may lead to a miscarriage of justice. In particular, law enforcement authorities could benefit from investigatory powers used by sports organisations if the use of equivalent measures is not warranted by the national criminal procedure code. ${ }^{50}$ Sports organisations and law enforcement authorities must therefore be prevented from circumventing the fundamental procedural rights of athletes. Otherwise, the provision of information during internal sports investigations may amount into "improper compulsion" 51 und would therefore be in violation of Article 6(1) of the ECHR. However, there seem to be no legitimate grounds to restrict athletes' privilege against self-incrimination. In its case law, the European Court of Human Rights ("ECtHR") generally accepts such limitations when passive investigatory powers are used, such as blood drawing. ${ }^{52}$ The reporting and cooperation obligations,

\footnotetext{
50 See CAS 2017/A/5003, Jérôme Valcke v. FIFA, Award of 27 July 2018, para 266; see also Hessert (2020a) 145, 152.

51 Saunders v. United Kingdom, ECtHR, Application No. 19187/91, 17 December 1996, para. 68.

52 Ibid, para. 69; Jalloh v. Germany, ECtHR, Application No. 54810/00, 11 July 2006, para. 102.
} 
in turn, concern an active support of sports investigations. Therefore, the best solution to deal with the dilemma faced by athletes is to permit the forced provision of information for the purpose of finding the truth in internal sports investigations. At the same time, in respect of the principle of nemo tenetur se ipsum accusare, sports organisations shall be prevented from sharing self-incriminating information with law enforcement agencies, irrespective of the state of criminal proceedings. Therefore, it is the obligation of sports organisations to ensure that no incriminating information is disclosed. Furthermore, in case sports organisations provide information to law enforcement authorities, incriminating information obtained on forced basis shall generally be inadmissible as evidence in criminal proceedings for the protection of the defence rights of athletes. This solution takes into account the very reason for the investigations conducted against the athlete while respecting their fundamental procedural rights in criminal proceedings.

\section{Conclusion}

The exchange of information between sports organisations and law enforcement raises some fundamental questions regarding the basic procedural rights of athletes, even if sports investigations and criminal proceedings are two distinct procedures. However, the criminalisation of sportsrelated conduct in national criminal codes results in the two processes being closely intertwined. The main purpose of internal sports investigations, nevertheless, remains the detection and prosecution of sports rule violations. Sports organisations shall therefore not become the extension of state authorities to the detriment of their direct and indirect members. Accordingly, it is pertinent to distinguish strictly between the investigation of internal matters and the assistance of external investigations.

This article has offered different legal solutions that could be applied to the dilemma of athletes who may be compelled to disclose incriminating information to sports organisations, while being aware that this information could be shared with law enforcement and ultimately used against them in criminal proceedings. The SFT made the application of the prohibition of incrimination during sports investigations dependent on the status of criminal proceedings, i.e. whether such proceedings were already pending or contemplated. Better solutions can be found when looking at other proceedings in which the persons under investigation are compelled to provide all information for internal matters. Based on this analysis, procedural and sporting fairness can best be ensured if information can only be used for internal matters to protect the integrity and the association life of sports associations. The inherent risk of passing incriminating information to law enforcement can only be countered if sports organisations are prevented from sharing such information and, if shared, the information is inadmissible as evidence in criminal proceedings. This way, on the one hand, athletes must fulfil their obligations under the respective sports regulations and, on the other hand, can be sure that their defence rights, in particular their privilege against self-incrimination, are guaranteed in criminal proceedings.

Perhaps we need another Valcke to challenge this pressing issue before the SFT. The time is not yet ripe, but fairness will slowly find its way into the parallelism of sports and criminal investigation proceedings in respect of the privilege against self-incrimination of athletes.

Funding Open Access funding provided by Universität Zürich.

Open Access This article is licensed under a Creative Commons Attribution 4.0 International License, which permits use, sharing, adaptation, distribution and reproduction in any medium or format, as long as you give appropriate credit to the original author(s) and the source, provide a link to the Creative Commons licence, and indicate if changes were made. The images or other third party material in this article are included in the article's Creative Commons licence, unless indicated otherwise in a credit line to the material. If material is not included in the article's Creative Commons licence and your intended use is not permitted by statutory regulation or exceeds the permitted use, you will need to obtain permission directly from the copyright holder. To view a copy of this licence, visit http://creativecommons.org/licenses/by/4.0/.

\section{Reference}

Beloff M, Netzle S, Haas U, Hessert B, Koller Trunz M (2021) The Court of Arbitration for Sport. In: Lewis A and Taylor J (eds) Sport: Law and Practice, 4th edn. Bloomsbury Professionals, New York, pp 1150-1228

Boss PV (2020) Duty to cooperate in disciplinary proceedings and its limitations deriving from standard rights in criminal proceedings-A review under Swiss law. CAS Bulletin 01:7-19

Diaconu M, Kuwelkar S, Kuhn A (2021) The court of arbitration for sport jurisprudence on match-fixing: a legal update. Int Sports Law J 21:27-46

Divitcos P (2020) Match-fixing in Sport: A Coordinated, Targeted and Comprehensive Network of Actors. ANZSLAJ 13(1):1-36

Geth C (2014) Selbstbelastungsfreiheit im Unternehmensstrafrecht Konflikt zwischen Moderne und Tradition aus schweizer Perspektive. ZSTW 126(1):105-121

Graf D (2016) Strafprozessuale Verwertbarkeit von Befragungsprotokollen interner Untersuchungen. forumpoenale 2016:39-44

Henzelin, M, Palermo, G and Mayr, T, Why national platforms are the cornerstone in the fight against match-fixing in sport: The Macolin Convention (LawInSport, 18 June 2018). https://www.lawinsport. $\mathrm{com} /$ topics/item/why-national-platforms-are-the-cornerstone-inthe-fight-against-match-fixing-in-sport-the-macolin-convention\# references. Accessed 25 Mar 2021

Hessert B (2020a) Cooperation and reporting obligations in sports investigations. Int Sports Law J 20:145-156. https://doi.org/10. 1007/s40318-020-00169-5

Hessert B (2020b) Against all Odds: The Legitimacy of the Use of Inside Information in Tennis. ANZSLAJ 13(1):133-154 
Lüke W (2017) § 97 Auskunfts- und Mitwirkungspflichten des Schuldners. In: Kübler B, Prütting H and Bork R (eds), InsO - Kommentar zur Insolvenzordnung, RWS Verlag Kommunikationsforum

Macula L (2016) Mitwirkungspflichten nach Art. 29 FINMAG - Zulässige Grenze strafprozessualer Selbstbelastungsfreiheit. recht, pp $30-46$

McLean H (2020) Coercive Powers for the New National Sports Tribunal: Could They be the Silver Bullet to Strengthen Integrity in Australia Sport. ANSZLAJ 13(1):37-50

Orth J (2021) Zusammenspiel und Wechselwirkung von staatlichen und Verbandsstrafverfahren. In: Cherkeh R, Momsen C and Orth J, Handbuch Sportstrafrecht, C.H. Beck, pp 305-317

Press Release, 'UCI update on testing for technological fraud during the 2018 Tour de France' (UCI, 30 July 2018). https://www.uci. org/inside-uci/press-releases/uci-update-on-testing-for-technologi cal-fraud-during-the-2018-tour-de-france. Accessed 24 Mar 2021

Riemer HM (1990) Berner Kommentar - Die Vereine. Stämpfli \& Cie AG, Bern
Rigozzi A and Quinn B (2014) Evidentiary Issues Before CAS. In: Bernasconi M (ed), International sports law and jurisprudence of the CAS - 4th CAS \& SAV/FSA conference Lausanne 2012, Editions Weblaw, pp 1-54

Rudolph R (2018) Interne Untersuchungen: Spannungsfelder aus arbeitsrechtlicher Sicht. Schweizerische Juristen-Zeitung 114(16):385-394

Truffer R (2019) Art. 29 FINMAG Auskunfts- und Mitwirkungspflichten. In: Watter R and Bahar R (eds), Basler Kommentar Finanzmarktaufsichtsgesetz/Finanzmarktinfrastrukturgesetz, Helbing Lichtenhahn Verlag

Publisher's Note Springer Nature remains neutral with regard to jurisdictional claims in published maps and institutional affiliations. 